\title{
Methodology for extracting activity from functional calcium imaging data
}

Allison Del Giorno ${ }^{1,2^{*}}$, Natalia Toporikova ${ }^{1,2}$, Nick Mellen ${ }^{3}$, Robert J Butera ${ }^{1,2}$

From Twenty First Annual Computational Neuroscience Meeting: CNS*2012

Decatur, GA, USA. 21-26 July 2012

Functional calcium imaging is a widespread technique used to measure the activity of multiple cells at a time. Because the activity traces from this data collection technique are noisy, we have developed a new method for extraction of activity episodes from the fluorescence traces. While Gaussian filters are commonly used for smoothing data, this technique alters the frequency of the activity episodes, so instead Butterworth filters are employed. We plotted the spectrograms of individual traces and visually determined the cutoff frequency that would remove the high-frequency noise. After smoothing (Figure 1A), we identify local minima by taking a modified

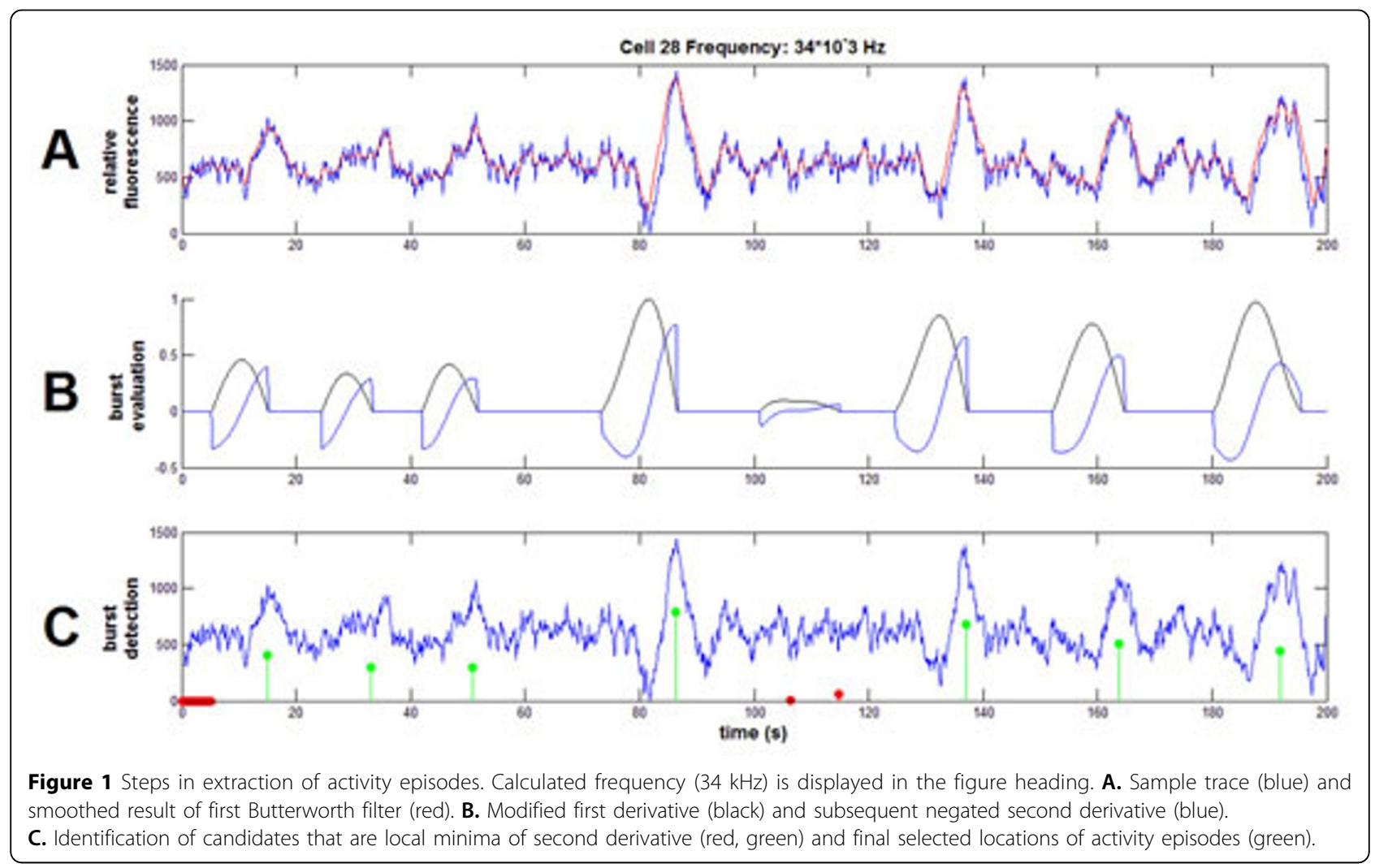

\footnotetext{
* Correspondence: allie.delgiorno@gatech.edu

'Electrical Engineering, Georgia Institute of Technology, Atlanta, Georgia

30332, USA

Full list of author information is available at the end of the article
} 
first derivative and then calculating the second derivative from this trace (Figure 1B). Local minima are then selected as activity episodes based on their corresponding first derivative values (Figure 1C). These activity locations are then used in the calculations for frequency of activity episodes. This method has several advantages for use with calcium data: (1) it is independent of the amplitude of the bursts; (2) the function is robust to drift in the trace; (3) the parameters are easily changed to adapt to ground truth data under differing experimental conditions.

\section{Author details}

'Electrical Engineering, Georgia Institute of Technology, Atlanta, Georgia 30332, USA. ${ }^{2}$ NeuroLab, Georgia Institute of Technology, Atlanta, Georgia, 30332, USA. 'Kosair Children's Hospital Research Institute, University of Louisville, Louisville, Kentucky, 40202, USA.

Published: 16 July 2012

doi:10.1186/1471-2202-13-S1-P173

Cite this article as: Del Giorno et al:: Methodology for extracting activity from functional calcium imaging data. BMC Neuroscience 2012 13(Suppl 1):P173.
Submit your next manuscript to BioMed Central and take full advantage of:

- Convenient online submission

- Thorough peer review

- No space constraints or color figure charges

- Immediate publication on acceptance

- Inclusion in PubMed, CAS, Scopus and Google Scholar

- Research which is freely available for redistribution

Submit your manuscript at www.biomedcentral.com/submit
Ciomed Central 